\title{
Helicobacter pylori in a Korean isolate activates mitogen-activated protein kinases, $A P-1$, and NF- $\kappa$ B and induces chemokine expression in gastric epithelial AGS cells
}

\author{
Ji Hye Seo, Joo Weon Lim, Hyeyoung Kim and Kyung Hwan Kim \\ Department of Pharmacology and Institute of Gastroenterology, Brain Korea 21 Project for Medical Sciences, \\ Yonsei University College of Medicine, Seoul, Korea
}

\begin{abstract}
Oxidant-sensitive transcription factors, nuclear factor- $\kappa$ B (NF- $\kappa B$ ), and activator protein-1 (AP-1) have been considered as the regulators of inducible genes such as chemokines. Since oxygen radicals are considered as an important regulator in the pathogenesis of Helicobacter pylori $(H$. pylori)-induced gastric ulceration and carcinogenesis, chemokines such as interleukin-8 (IL-8) and monocyte chemoattractant protein-1 (MCP-1) may be regulated by NF- $\kappa$ B and/or AP-1. Ras, the upstream activator for mitogen-activated protein kinase (MAPK) and MAPK cascade regulate AP-1 activation. The present study aims to investigate whether $H$. pylori in a Korean isolate (HP99) induces the expression of chemokines (IL-8, MCP-1), which is regulated by Ras, MAPK, AP-1, and $\mathrm{NF}-\kappa \mathrm{B}$ in gastric epithelial AGS cells, and whether these transcriptional regulations of chemokines are inhibited by transfection with mutant genes for Ras (ras N-17), c-Jun (TAM-67), and I $\kappa \mathrm{B} \alpha$ (MAD-3) or treatment with MAPK inhibitors (U0126 for extracellular signal-regulated kinase or SB203580 for p38 kinase). In addition, virulence factors of HP99 were characterized by PCR analysis for the isolated DNA. As a result, HP99 is identified as $\operatorname{cagA}+$, vacA s1b, m2, iceA1 H. pylori strain. HP99 induced a time-dependent expression of mRNA and protein for IL-8 and MCP-1 via mediation of MAPK, AP-1, and NF- $k$ B. Transfection with mutant genes for Ras, c-Jun, and $I_{\kappa} B \alpha$ and treatment with MAPK inhibitors suppressed $H$. pylori-induced activation of transcription factors (NF- $\kappa$ B, AP-1) and expression of chemokines (IL-8, MCP-1) in AGS cells. In conclusion, Ras and MAPK cascade may act as the upstream signaling for the activation of AP-1 and NF- $\kappa B$, which induce chemokine expression in H. pylori-infected AGS cells. Specific targeting of the activation of NF- $\kappa$ B and AP-1 may be effective for the prevention or treatment of gastric inflammation associated with $\boldsymbol{H}$. pylori infection.
\end{abstract}

Laboratory Investigation (2004) 84, 49-62, advance online publication, 20 November 2003; doi:10.1038/labinvest.3700010

Keywords: Helicobacter pylori; chemokine; nuclear factor- $\kappa \mathrm{B}$; mitogen-activated protein kinase; activator protein1; gastric epithelial AGS cells

Helicobacter pylori (H. pylori) infection is an important risk factor for chronic gastritis, peptic ulcer, and gastric carcinoma. $^{1,2}$ Since $H$. pylori exhibits chemotactic activity for neutrophils, one of the potential toxic factors involving $H$. pyloriinduced gastric injury is oxygen radicals released from activated neutrophils. ${ }^{3}$ However, our previous study showed that $H$. pylori-induced oxygen radicals in gastric epithelial cells in the absence of inflammatory cells. ${ }^{4,5}$ These results demonstrate the possibility that $H$. pylori directly turns on transcrip-

Correspondence: H Kim, Department of Pharmacology, Yonsei University College of Medicine, Seoul 120-752, Korea.

E-mail: kim626@yumc.yonsei.ac.kr

Received 12 September 2003; revised 02 October 2003; accepted 05 October 2003; published online 20 November 2003 tion levels of inflammatory genes in gastric epithelial cells prior to the recruitment of inflammatory cells.

Chemoattractant cytokines (chemokines) form a superfamily of closely related secreted proteins that specialize in mobilizing leukocytes to areas of immune challenge. ${ }^{6}$ These inducible proinflammatory peptides potently stimulate leukocyte migration along a chemotactic gradient. They also modulate leukocyte adhesion, activate signal transduction cascades leading to novel gene expression programs, and mediate other leukocyte function necessary for leukocytes to leave the circulation and infiltrate tissues. Chemokines are divided into groups that are defined by characteristic cysteine motifs. Four families of chemokines, such as CXC, CC, C and $\mathrm{CX}_{3} \mathrm{C}(\mathrm{C}$ is a conserved cysteine residue and $\mathrm{X}$ is any 
other amino acid), have been described. ${ }^{7}$ Among these chemokines, interleukin-8 (IL-8), a prototype CXC chemokine, seems to play an important role in recruiting and activating neutrophils in the gastric mucosa. ${ }^{8}$ Several reports suggest that gastric epithelial cells represent an important source of IL-8.$^{8,9}$ In addition to chemotactic potential, IL-8 is capable of activating polymorphonuclear leukocyte degranulation, the respiratory burst, and the 5-lipoxygenase pathway. ${ }^{6}$ Thus, IL-8 may be a component of the inflammatory cascade. Indeed, gastric mucosal levels of IL-8 correlates with histological severity in patients with $H$. pylori-induced gastritis. ${ }^{8}$ Prolonged IL-8 production by gastric epithelial cells during $H$. pylori infection could result in the recruitment of leukocytes to infected tissues and therefore may be important in the regulation of inflammatory and immune processes in response to H. pylori. ${ }^{10}$ Since chronic $H$. pylori-associated gastritis is accompanied by monocyte and lymphocyte infiltration, in addition to neutrophil infiltration, we were interested in determining whether members of the CC subfamily of chemokines, which recruit monocytes ad lymphocytes, participated in H. pylori-associated pathogenesis. Monocyte chemoattractant protein 1 (MCP-1) is a CC chemokine that stimulates mononuclear leukocytes. Like IL-8 induction, the in vivo expression of MCP-1 is elevated in the gastric mucosa following $H$. pylori infection. ${ }^{11}$ $H$. pylori infection of gastric epithelial cell lines also stimulates MCP-1 expression. ${ }^{11}$ Expression of the inflammatory gene such as IL-8 and MCP-1 is primarily controlled at the transcriptional level. Nuclear factor- $\kappa \mathrm{B}(\mathrm{NF}-\kappa \mathrm{B})$ and activator protein-1 (AP-1) are inducible transcription factors and their binding sites are found in the promoter region of both IL-8 and MCP-1 genes. ${ }^{12}$ Although the importance of these transcription factors in chemokine production is apparent, it remains unclear as to how $H$. pylori could activate these transcription factors and induce chemokine expression. Since these transcription factors are thought to be activated by oxygen radicals, ${ }^{13}$ oxygen radicals generated by $H$. pylori may trigger the activation of these transcription factors in gastric epithelial cells.

$\mathrm{NF}-\kappa \mathrm{B}$ is a member of the Rel family including p50 (NF- $\kappa \mathrm{B} 1)$, p52(NF- $\kappa \mathrm{B} 2$ ), Rel A (p65), c-Rel, Rel $\mathrm{B}$, and Drosophila morphogen dorsal gene product. ${ }^{14}$ Its activity is controlled by its cytoplasmic inhibitory protein $\mathrm{I} \kappa \mathrm{B}-\alpha .{ }^{15}$ Previously, we found that $H$. pylori increased lipid peroxidation, an indication of oxidative damage, and induced the activation of two species of NF- $\kappa$ B dimers (a p50/p65 heterodimer and a p50 homodimer) in gastric epithelial cells. ${ }^{4,5}$ Pyrrolidine dithiocarbamate (PDTC), a proven free radical scavenger and $\mathrm{NF}-\kappa \mathrm{B}$ inhibitor, potentially inhibits $N F-\kappa B$ interaction with its upstream regulatory binding site thereby preventing NF- $\kappa \mathrm{B}-$ mediated transcriptional activation in $H$. pyloriinfected gastric epithelial cells. ${ }^{16}$ AP-1 is composed of homodimers or heterodimers of members of Fos and Jun families, which binds to the TRE (TPA responsive element) motif to mediate gene transcription. In relation to $H$. pylori infection, transcription of IL-8 gene was reported to require the activation of NF- $\kappa \mathrm{B}$ and, to a lesser extent, AP-1 in human gastric epithelial MKN 45 cells, ${ }^{17}$ Kato III cells, ${ }^{18}$ and AGS cells. ${ }^{19} \mathrm{H}$. pylori-induced MCP-1 expression is mediated by NF- $\kappa \mathrm{B}$ in gastric epithelial cells. ${ }^{20,21} \mathrm{H}$. pylori strongly induced AP-1 DNA binding and selectively activated the mitogenactivated protein kinase (MAPK) cascade in gastric epithelial cells. ${ }^{22}$ Therefore, chemokine gene transcription may require the activation of the combination of $\mathrm{NF}-\kappa \mathrm{B}$ and $\mathrm{AP}-1$, or that of $\mathrm{NF}-\kappa \mathrm{B}$ and CCAAT/enhancer binding protein (C/EBP). This may depend on the types of cell or stimuli since there are binding sites for $\mathrm{NF}-\kappa \mathrm{B}, \mathrm{AP}-1$, and $\mathrm{C} / \mathrm{EBP}$ in the promoter regions of IL-8 and MCP-1 genes.

Three major subfamilies of MAPKs have been identified in mammalian cells: the extracellular signal-regulated kinases (ERKs), the c-Jun NH2terminal protein kinases (JNKs) or stress-activated protein kinases (SAPKs), and the p38 MAPKs. ${ }^{23} \mathrm{AP}-$ 1 activity is regulated by all three MAPK pathways. $^{24}$ Transcriptions of $\mathrm{c}-\mathrm{fos}^{25}$ and $\mathrm{c}-\mathrm{jun}^{26}$ are upregulated by activated MAPK. Post-transcriptionally, c-Jun activity is potentiated through phosphorylation of the transcriptional activator domain by SAPK/JNK. ${ }^{27} \mathrm{H}$. pylori activated AP-1 through ERK signaling $^{22,28}$ and JNK signaling ${ }^{29}$ in gastric epithelial cells. A variety of extracellular stimuli induce ras activation, resulting in activation of the ras/raf/ ERK kinase/MAPK cascade. ${ }^{30}$ The Ras-Raf pathway increases the transcriptional activity of transcription factor such as c-Jun, an important component of AP$1 .^{31}$ Ras dominant-negative gene expression almost blocked p38 phosphorylation in smooth muscle cells. ${ }^{32}$ These studies suggest that Ras is the upstream activator for MAPK, and thus may be related to AP-1 activation.

Molecular genetic analysis of $H$. pylori has shown that approximately $50-60 \%$ of strains have a $40 \mathrm{~kb}$ DNA segment called the cytotoxin-associated gene $(\operatorname{cag} A)$ pathogenecity island (PAI). ${ }^{33}$ Some of the proteins encoded by $\operatorname{cag} A$ PAI genes are responsible for oxidant-sensitive transcription factor NF- $\kappa \mathrm{B}$ and MAPK activation in gastric epithelial cells. ${ }^{34}$ Infection by $\operatorname{cag} A$ strain is more likely to result in peptic ulceration, atrophic gastritis, and gastric carcinoma. ${ }^{35,36} \mathrm{H}$. pylori isolates show a high degree of genetic variability. ${ }^{1,37}$ These genetic differences may play a role in the clinical outcome of the infection, particularly $H$. pylori-virulence-associated genes such as vacA, $\operatorname{cag} A$, and ice $A$ genes. ${ }^{38,39}$ The predominant genotype of $H$. pylori in Korea has been reported as $\operatorname{cag} A$-positive and vacA-positive genotype. ${ }^{40,41}$

We conducted the present study to evaluate whether $\operatorname{cag} A+, \operatorname{vac} A+H$. pylori strain from a Korean isolate induces the expression of chemokines (IL-8, MCP-1), which is mediated by MAPK 
activation (ERK, JNK, p38) and oxidant-sensitive transcription factors, NF- $\kappa \mathrm{B}$ and AP-1. We also assessed whether $H$. pylori-induced chemokine expression is inhbited by transfection with mutant genes for Ras, c-Jun, and $\mathrm{I} \kappa \mathrm{B} \alpha$ genes to inhibit Ras, $\mathrm{AP}-1$, and NF- $\kappa \mathrm{B}$ activation, respectively, and treatment of specific inhibitors for ERK (U0126) and p38 (SB203580) in gastric epithelial AGS cells. Prior to the experiment, virulence factors ( $\operatorname{cag} A$, vacA, ice $A$ ) of $H$. pylori from a Korean isolate were characterized by polymerase chain reaction (PCR) analysis.

\section{Materials and methods}

\section{Bacterial Strain and Culture Condition}

An H. pylori strain (HP99) was isolated from gastric antral mucosa obtained from a Korean patient with duodenal ulcer at Seoul National University. HP99 was identified as $\operatorname{cag} A+, \operatorname{vac} A+$ positive strain. ${ }^{42,43}$ HP99 was kindly provided by Dr HC Jung (Seoul National University College of Medicine, Seoul, Korea). These bacteria were inoculated onto chocolate agar plates (Becton Dickinson Microbiology Systems, Cockeysville, MD, USA) at $37^{\circ} \mathrm{C}$ under microaerophilic conditions using an anaerobic chamber (BBL Campy Pouch ${ }^{\circledR}$ System, Becton Dickinson Microbiology Systems).

\section{Determination of Virulence Factors of $\boldsymbol{H}$. pylori (HP99)}

H. pylori genomic DNA was extracted with the QIAGEN Genomic DNA purification kit (QIAGEN, Inc., Valencia, CA, USA) according to the manufacturer's instruction. PCR was performed using specific primers for $\operatorname{cag} A, \operatorname{vac} A$, and ice $A$ genes because these genes have been reported to be virulence factors of $H$. pylori. ${ }^{38,39}$ Bacterial genomic DNA was amplified in a $50 \mu \mathrm{l}$ of $10 \mathrm{mM}$ Tris- $\mathrm{HCl}(\mathrm{pH}$ 8.3), $50 \mathrm{mM} \mathrm{KCl}, 1.5 \mathrm{mM} \mathrm{MgCl}_{2}, 200 \mu \mathrm{M}$ of each dNTP, $2 \mu \mathrm{l}$ of genomic DNA, $2.5 \mathrm{U}$ of Taq DNA polymerase, and $25 \mathrm{pmol}$ of specific primer sets described below. PCR amplification was performed for 50 cycles, with one cycle consisting of $45 \mathrm{~s}$ at $95^{\circ} \mathrm{C}, 1 \mathrm{~min}$ at $55^{\circ} \mathrm{C}$, and $1 \mathrm{~min} 30 \mathrm{~s}$ at $72^{\circ} \mathrm{C}$. The final cycle included a 5 min extension step to ensure full extension of the PCR products. For detection of the $\operatorname{cag} A$ gene, primers CAGAF and CAGAR which yield a fragment of $349 \mathrm{bp}$ from the middle conservative region of the $\operatorname{cag} A$ gene, were used). ${ }^{41}$ For analysis of the vacA s region, primers VA1-F, VA1-R were used as described by Atherton et $a 1^{4,45}$ Primers VA1-F and VA1-R yielded a fragment of $259 \mathrm{bp}$ for s1 variants. Each isolate was typed s1a or $\mathrm{s} 1 \mathrm{~b}$ or s1c by performing PCR using primers S1A-F-VA1-R, SS3$\mathrm{F}-\mathrm{VA} 1-\mathrm{R}$, and S1C-F-VA1-R, repectively. For analysis of the vacA $\mathrm{m}$ region, primers VA3-FVA3-R, and VA4-F-VA4-R yielded a fragment of $290 \mathrm{bp}$ for $\mathrm{m} 1$ variants and a fragment of $352 \mathrm{bp}$ for $\mathrm{m} 2$ variants. ${ }^{44}$ For analysis of the ice $A$ genotype, primers ice $A 1 \mathrm{~F}$, ice $A 1 \mathrm{R}$, ice $A 2 \mathrm{~F}$, ice $A 2 \mathrm{R}$ were used as previously described. ${ }^{46,47}$ Primers ice $A 1 \mathrm{~F}$ and ice $A 1 \mathrm{R}$ yielded a fragment of $247 \mathrm{bp}$ for the ice $A 1$ allele, and primers ice $A 2 \mathrm{~F}$ and ice $A 2 \mathrm{R}$ yielded a fragment of 229 or $334 \mathrm{bp}$ depending on the presence of repeated sequences of 105 nucleotides.

\section{Cell Line and $H$. pylori Infection}

Human gastric cancer AGS cells (gastric adenocarcinoma, ATCC CRL 1739) were obtained from the American Type Culture Collection (Rockville, MD, USA) and cultured in RPMI-1640 medium (pH 7.4; Sigma, St Louis, MO, USA), supplemented with $10 \%$ fetal bovine serum, $4 \mathrm{mM}$ glutamine (GIBCOBRL, Grand Island, NY, USA), antibiotics (100 U/ml penicillin and $100 \mu \mathrm{g} / \mathrm{ml}$ streptomycin). The cells were seeded in 12-well cell culture plates at $10^{5}$ cells per well in a volume of $1 \mathrm{ml}$ and cultured to reach $80 \%$ confluency. Prior to stimulation, each well was washed twice with $1 \mathrm{ml}$ of fresh cell culture medium containing no antibiotics. Bacterial cells were harvested, washed with phosphatebuffered saline (PBS), and then resuspended in antibiotic-free cell culture medium. The bacterial cells were added to the cultured cells at a bacterium/ cell ratio of 500:1 in a $1 \mathrm{ml}$ volume. A ratio of bacterium/cell was adapted from previous studies. ${ }^{4,5,48}$ Supernatants were collected for the determination of IL-8 and MCP-1 at the indicated time points. The cells were homogenized and RNA was extracted for the determination of IL-8 and MCP-1 mRNA expression. Cell lysates were analyzed for control and phospho-specific ERK1/2, JNK1/2, and p38 level by Western blot analysis and nuclear extracts were used for the levels of NF- $\kappa \mathrm{B}, \mathrm{AP}-1$, and C/EBP by electrophoretic mobility shift assay (EMSA).

\section{Experimental Protocol}

To determine whether HP99 induces activation of transcription factors (NF- $\kappa \mathrm{B}, \mathrm{AP}-1, \mathrm{C} / \mathrm{EBP})$ and MAPK (ERK1/2, JNK2/1, p38), and the expression of chemokines (IL-8, MCP-1) in AGS cells, AGS cells were cultured in the presence of HP99 for $12 \mathrm{~h}$. To determine the involvement of Ras, AP-1, and NF- $\kappa \mathrm{B}$ on chemokine expression, AGS cells were treated with MAPK inhibitors and transfected with mutant genes for Ras, c-Jun, and $\mathrm{I} \kappa \mathrm{B} \alpha$ and cultured in the absence and presence of HP99 for $12 \mathrm{~h}$. mRNA and protein expression of chemokines were determined by RT-PCR analysis and enzyme-linked immunosorbent assay (ELISA) (at 12 hour). The activation of transcription factors was assessed by electrophoretic mobility shift assay (EMSA) using nuclear extracts of the cells (at $1 \mathrm{~h}$ ). MAPK activation was evaluated by Western blot analysis at the indicated time points (up to $180 \mathrm{~min}$ ). The MAP kinase inhibitors, U0126 (an ERK inhibitor, Catalog \# 9903, Cell Signaling 
Technology, Inc., Beverly, MA, USA) and SB203580 (a p38 inhibitor, Catalog \# 559389, Calbiochem Biochemicals, San Diego, CA, USA), were purchased and dissolved in dimethylsulfoxide at $50 \mathrm{mM}$ of stock solution. The inhibitors, at $20 \mu \mathrm{M}$ final concentration, were pretreated to the culture medium $1 \mathrm{~h}$ before the treatment of $H$. pylori.

\section{Transfection with Mutant Genes for Ras, c-Jun, and IkBk}

A mutated $\mathrm{I} \kappa \mathrm{B} \alpha$ gene, MAD-3 double point mutant (substitution of two serine residues at positions 32 and 36 by alanine residues) construct was prepared as described previously. ${ }^{49}$ By transfection of MAD-3 into the cells, $\mathrm{I} \kappa \mathrm{B} \alpha$ could not be phosphorylated, which inhibits NF- $\kappa \mathrm{B}$ activation. A dominantnegative mutant of C-Jun, called TAM-67, is a potent inhibitor of AP-1-mediated transactivation. ${ }^{50} \mathrm{~A}$ dominant-negative mutant lacking the transactivation domain of c-Jun can dimerize with c-Jun or c-Fos family members, and can bind DNA. Thus, such a mutant could inhibit the function of wildtype c-Jun and c-Fos through either a blocking or quenching mechanism. ${ }^{51}$ TAM-67 was a kind gift from Dr Andreas von Knethen (University of Erlangen, Erlangen, Germany). Transfection of a dominant-negative mutant of ras, called ras $\mathrm{N}-17$, into the cells interferes with ras function by the expression of a dominant inhibitory mutation in c-Ha-ras. This mutation changes serine- 17 to arginine-17 in the gene product and thus inhibits ras activity. ${ }^{52}$ Ras N17 was kindly provided by Dr SY Song (Yonsei University College of Medicine, Seoul, Korea). The control vector pcDNA3 (Invitrogen Corp., Carlsbad, CA, USA) was transfected to the cells instead of mutant genes for ras (ras N-17), c-Jun (TAM-67), and $\mathrm{I} \kappa \mathrm{B} \alpha$ (MAD-3). These cells were considered as a relative control and named pcN-3.

Subconfluent AGS cells, plated in a $10 \mathrm{~cm}$ culture plate $\left(6 \times 10^{5}\right.$ cells per plate), were transfected with each $10 \mu \mathrm{g}$ of expression construct using DOTAP $(\mathrm{N}$ [1-(2,3-dioleoyloxy) propyl]- $N, N, N$ trimethyl ammonium methylsulfate) (Boehringer-Mannheim, Pentzberg, Germany) for $16 \mathrm{~h}$. After transfection, the cells were trypsinized and plated at $1 \times 10^{5}$ cells per 12 well plate. The cells were cultured in the presence or absence of $H$. pylori. Electrophoretic mobility shift assays for NF- $\kappa$ B and AP-1 were performed at 1 h-culture (Figure 6) while the levels of mRNA and protein for chemokines (Figure 5) were determined at $12 \mathrm{~h}$ culture (Figure 5) in the cells transfected with control vector (pcN-3) or mutant genes (ras N-17, TAM-67, MAD-3). AGS cells without transfection were cultured in the presence of $H$. pylori (control) or absence of $H$. pylori (none).

\section{Western Blot Analysis for ERK, JNK, and p38}

The AGS cells were cultured in the presence of $H$. pylori for $180 \mathrm{~min}$ (Figure 4). At an indicated time point, the cells were trypsinized, washed, and homogenized in Tris-HCl (pH 7.4) buffer containing $0.5 \%$ Triton X-100 and protease inhibitor cocktail (Boehringer Mannheim, Indianapolis, IN, USA) for determination of control and phospho-specific ERK1/2 (p44/p42), JNK 2/1 (p54/p46), and p38. The protein concentration of each sample was determined by Bradford assay (Bio-Rad laboratories, Hercules, CA, USA). Cellular protein $(100 \mu \mathrm{g})$ was loaded per lane, separated by $10 \%$ SDSpolyacrylamide gel electrophoresis under reducing conditions, and transferred onto nitrocellulose membranes (Amersham Inc., Arlington Heights, IL, USA) by electroblotting. The transfer of protein and equality of loading in all lanes was verified using reversible staining with Ponceau S. The membranes were blocked using $5 \%$ nonfat dry milk in TBS-T (Tris-buffered saline and $0.15 \%$ Tween 20) for $3 \mathrm{~h}$ at room temperature. The proteins were detected with polyclonal antibodies for panERK1/2 (p44/p42) (Catalog \# 9102), phosphoERK1/2 (Catalog \# 9101), pan-JNK 2/1 (p54/p46) (Catalog \# 9252), phospho- JNK 2/1 (p54/p46) (Catalog \# 9251), pan-p38 (Catalog \# 9212), and phospho-p38 (Catalog \# 9211) at 1:2000 dilation (all from Cell Signaling Technology, Inc., Bevery, MA, USA) diluted in TBS-T containing 5\% dry milk, and incubated at $4^{\circ} \mathrm{C}$ overnight. After washing in TBS-T, the immunoreactive proteins were visualized using goat anti-rabbit secondary antibodies conjugated to horseradish peroxidase, which was followed by enhanced chemiluminescence (Amersham). Exactly equal amount of protein, determined by Bradford assay (Bio-Rad laboratories), was loaded in each lane. The Western blot result presented in each figure is representative of five separate experiments.

\section{Extraction of Nuclei}

The cells treated with inhibitors for ERK (U0126) and p38 (SB203580) or transfected with mutant genes (ras N-17, TAM-67, MAD-3) or control vector (pcN-3) were cultured in the presence or absence of $H$. pylori for $1 \mathrm{~h}$. The cells were rinsed with ice-cold PBS, harvested by scraping into PBS, and pelleted by centrifugation at $1500 \mathrm{~g}$ for $5 \mathrm{~min}$. The cells were lysed in buffer containing $10 \mathrm{mM}$ HEPES, $10 \mathrm{mM}$ $\mathrm{KCl}, \quad 0.1 \mathrm{mM}$ ethylenediaminetetraacetic acid (EDTA), $1.5 \mathrm{mM} \mathrm{MgCl}_{2}, 0.2 \%$ Nonidet P-40, $1 \mathrm{mM}$ dithiothreitol (DTT), and $0.5 \mathrm{mM}$ phenylmethylsulfonylfluoride (PMSF). The nuclear pellet was resuspended on ice in nuclear extraction buffer containing $20 \mathrm{mM}$ HEPES, $420 \mathrm{mM} \mathrm{NaCl}, 0.1 \mathrm{mM}$ EDTA, $1.5 \mathrm{mM} \mathrm{MgCl} 2,25 \%$ glycerol, $1 \mathrm{mM}$ DTT, and $0.5 \mathrm{mM} \mathrm{PMSF}^{53}$ and the nuclear protein concentration was determined by Bradford assay (Bio-Rad laboratories). AGS cells without transfection were cultured in the presence of $H$. pylori (control) or absence of $H$. pylori (none) in Figures 6 and 8. For 
time-course experiment, AGS cells were cultured in the presence of $H$. pylori for 4 hours (Figure 3).

\section{Electrophoretic Mobility Shift Assay}

$\mathrm{NF}-\kappa \mathrm{B}$ gel shift oligonucleotide (5'-AGTTGAGGGGACTTTCCCAGGC-3'), AP-1 gel-shift oligonucleotide (5'-CGCTTGAT AGTCAGCCGGAA-3'), or C/EBP (CCAAT/enhancer binding protein) gel-shift oligonucleotide (5'-GTACACATTGCACAATCTTA-3') (all from Promega Corp, Madison, WI, USA) was labeled with $\left[{ }^{32} \mathrm{P}\right] \mathrm{dATP}$ (Amersham) using T4 polynucleotide kinase (GIBCO-BRL). End-labeled probe was purified from unincorporated $\left.{ }^{32} \mathrm{P}\right] \mathrm{dATP}$ using a Bio-Rad purification column (Bio-Rad Laboratories, Hercules, CA, USA) and recovered in Tris-EDTA buffer (TE). Nuclear extracts ( $5 \mu \mathrm{g}$ ) were preincubated in buffer containing $12 \%$ glycerol; $12 \mathrm{mM}$ Hepes, $\mathrm{pH}$ 7.9; $4 \mathrm{mM}$ Tris-HCl, $\mathrm{pH}$ 7.9; $1 \mathrm{mM}$ EDTA; $1 \mathrm{mM}$ DTT; $25 \mathrm{mM} \mathrm{KCl;} 5 \mathrm{mM}$ $\mathrm{MgCl}_{2} ; \quad 0.04 \mu \mathrm{g} / \mathrm{ml}$ poly[d(I-C)](Boehringer Mannheim, Indianapolis, IN, USA); 0.4 mM PMSF; and TE. The labeled probe was added and samples were incubated on ice for $10 \mathrm{~min}$. The samples were subjected to electrophoretic separation at room temperature on a nondenaturing 5\% acrylamide gel at $30 \mathrm{~mA}$ using $0.5 \times$ Tris borate EDTA buffer. The gels were dried at $80^{\circ} \mathrm{C}$ for $1 \mathrm{~h}$ and exposed to a radiography film for $6-18 \mathrm{~h}$ at $-70^{\circ} \mathrm{C}$ with intensifying screens. ${ }^{53}$

\section{Reverse Transcription-Polymerase Chain Reaction (RT-PCR) Analysis for Chemokines}

Gene expressions of IL-8 and MCP-1 mRNA were assessed using RT-PCR standardized by coamplifying this gene with the housekeeping gene $\beta$-actin, which served as an internal control. The cells, treated with inhibitors for ERK (U0126) and p38 (SB203580) or transfected with mutant genes (ras N17, TAM-67, MAD-3) or control vector (pcN-3), were cultured in the presence or absence of $H$. pylori for $12 \mathrm{~h}$. Total RNA was isolated from the cells by guanidine thiocyanate extraction method. Total RNA was reverse transcribed into cDNA and used for PCR with human specific primers for IL-8, MCP1 , and $\beta$-actin. Sequences of IL-8 primers were $5^{\prime}$-ATGACTTCCAAGCTGGCCGTGGCT-3' (forward primer) and 5'-TCTCAGCCCTCTTCAAAAACTTCT$3^{\prime}$ (reverse primer), giving a $297 \mathrm{bp}$ PCR product. Sequences of MCP-1 primers were 5 -AAGCTGTG ATCTTCAAGACCATTG-3' (forward primer), $5^{\prime}$-TTAA GGCATAATGTTTCACATCAACAA- ${ }^{\prime}$ (reverse primer) giving a $269 \mathrm{bp}$ PCR product. For $\beta$-actin, the forward primer was 5'-ACCAACTGGGACGACATGGAG- $3^{\prime}$ and the reverse primer was $5^{\prime}$-GTGAGGATCTTCATGAGGTAGTC-3', giving a $349 \mathrm{bp}$ PCR product. Briefly, the PCR was amplified by $25-30$ repeat denaturation cycles at $95^{\circ} \mathrm{C}$ for $30 \mathrm{~s}$, annealing at $60^{\circ} \mathrm{C}$ for $30 \mathrm{~s}$, and extension at $72^{\circ} \mathrm{C}$ for $30 \mathrm{~s}$.
During the first cycle, the $95^{\circ} \mathrm{C}$ step extended to $2 \mathrm{~min}$, and on the final cycle the $72^{\circ} \mathrm{C}$ step extended to $5 \mathrm{~min}$. PCR products were separated on $1.5 \%$ agarose gels containing $0.5 \mu \mathrm{g} / \mathrm{ml}$ ethidium bromide and visualized by UV transillumination. AGS cells without transfection were cultured in the presence of $H$. pylori (control) or absence of $H$. pylori (none) in Figures 5 and 7. For time-course experiment, AGS cells were cultured in the presence of $H$. pylori for $12 \mathrm{~h}$ (Figure 2).

\section{Determination of IL-8 and MCP-1}

The cells treated with inhibitors for ERK (U0126) and p38 (SB203580) or transfected with mutant genes (ras N-17, TAM-67, MAD-3) or control vector (pcN-3) were plated at $10^{5}$ cells/well in a 12 well culture plate and cultured in the presence or absence of $H$. pylori for $12 \mathrm{~h}$. The levels of IL-8 and MCP-1 were determined in the medium by enzymelinked immunosorbent assay (ELISA) kits (R\&D System, Minneapolis, MN, USA). AGS cells without transfection were cultured in the presence of $H$. pylori (control) or absence of $H$. pylori (none) in Figures 5 and 7. For time-course experiment, AGS cells were cultured in the presence of $H$. pylori for $12 \mathrm{~h}$ (Figure 2).

\section{Statistical Analysis}

The results are expressed as means \pm s.d. of four separate experiments. Analysis of variance (ANOVA) followed by Newman-Keul's test was used for statistical analysis. $P<0.05$ was considered to be statistically significant.

\section{Results}

\section{Virulence factors in $\boldsymbol{H}$. pylori (HP99)}

An H. pylori strain (HP99) was isolated from gastric antral mucosa obtained from a Korean patient with duodenal ulcer. HP99 was previously identified as $\operatorname{cag} A+, \quad \operatorname{vac} A+$ positive strain., ${ }^{4,5}$ $V a c A$, encoding the vacuolating toxin, is present in all strains, ${ }^{45,54}$ and comprises two regions of allelic variation. ${ }^{44}$ The s-region, located at the $5^{\prime}$ end of the gene, and the m-region, located in the middle of $\operatorname{vac} A{ }^{46,47}$ The production of the cytotoxin is related to the mosaic combination of s- and m-region alleles in vacA. The cytotoxin-associated gene $(\operatorname{cag} A)$ is expressed by the majority of the cytotoxin (vacA)-positive isolates. ${ }^{55}$ Another virulence factor ice $A$ (induced by contact with epithelium) locus comprises two main variants, ice $A 1$ and ice $A 2 .{ }^{56}$ Even though the function of these variants is not yet clear, the combination for the virulence factors and their allelic variants may affect clinical outcome associated with $H$. pylori infection. $H$. pylori in a Korean isolate (HP99) used 
in the present study is identified as $\operatorname{cag} A+, \operatorname{vac} A$ $\mathrm{s} 1 \mathrm{~b}, \mathrm{~m} 2$, ice $A 1 H$. pylori strain, determined by PCR analysis for genomic DNA isolated from HP99 (Figure 1).

\section{Time-dependent Expression of IL-8 and MCP-1 by H. pylori}

mRNA expression (Figure 2a) and protein level (Figure 2b) of IL-8 and MCP-1 were determined in H. pylori-treated AGS cells. RT-PCR analysis shows that IL-8 and MCP-1 mRNA expression were observed at $4 \mathrm{~h}$ and 8 , respectively, and increased at $12 \mathrm{~h}$ incubation (Figure 2a). As shown in Figure $2 \mathrm{~b}$, IL-8 and MCP-1 protein increased in a timedependent manner up to $24 \mathrm{~h}$. IL-8 levels in medium $(\mathrm{pg} / \mathrm{ml})$ released from the cells at the start of experiment was $5.8 \pm 0.4$, which increased by $H$. pylori to $15.1 \pm 1.1,24.6 \pm 4.7$, and $51.2 \pm 6.3$ at culture time of 4,8 , and $12 \mathrm{~h}$, respectively. MCP-1 levels in medium $(\mathrm{pg} / \mathrm{ml})$ released from the cells at the start of experiment was $0.6 \pm 0.2$, which increased by $H$. pylori to $9.5 \pm 0.3,14.1 \pm 0.7$, and $44.5 \pm 1.9$ at culture times of 4,8 and $12 \mathrm{~h}$, respectively. Thus, for the following experiments using transfection with mutant genes and treatment with MAPK inhibitors, the time point of $12 \mathrm{~h}$, at which chemokine mRNA and protein expression were evident, was used. $\beta$-Actin was constitutively expressed in AGS cells and not changed with incubation time.

\section{H. pylori-induced Activation of NF- $\kappa \mathrm{B}$ and AP-1}

The bacterial cells were added to the cultured cells at a bacterium/cell ratio of 500:1. The cells were harvested and nuclear extracts were subjected to EMSA for the activation of NF- $\kappa \mathrm{B}, \mathrm{AP}-1$, and C/EBP at the indicated time points. Figure 3 shows autoradiographs from EMSA for NF- $\kappa \mathrm{B}$, AP-1, and C/EBP in AGS cells cultured in the presence of $H$. pylori for $4 \mathrm{~h}$. $H$. pylori resulted in the activation of NF- $\kappa$ B and AP-1 while C/EBP was not affected.

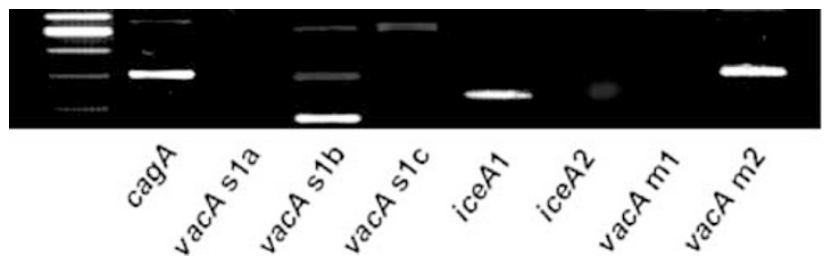

Figure 1 Determination of virulence factors in $H$. pylori (HP99). $H$. pylori genomic DNA was extracted and PCR was performed using specific primers for $\operatorname{cag} A$, vac $A$, and ice $A$ genes. Bacterial genomic DNA was amplified in a $50 \mu \mathrm{l}$ of $10 \mathrm{mM}$ Tris-HCl (pH 8.3), $50 \mathrm{mM} \mathrm{KCl}, 1.5 \mathrm{mM} \mathrm{MgCl}_{2}, 200 \mu \mathrm{M}$ of each dNTP, $2 \mu \mathrm{l}$ of genomic DNA, $2.5 \mathrm{U}$ of Taq DNA polymerase, and 25 pmol of specific primer sets for $\operatorname{cag} A, \operatorname{vac} A$ (s1a, s1b, s1c, m1, m2), and ice $A 1$ and ice $A 2$ genes. $H$. pylori in Korean isolates (HP99) is identified as $\operatorname{cag} A+$, vacA s1b, $\mathrm{m} 2$, ice $A 1 H$. pylori strain.
$\mathrm{NF}-\kappa \mathrm{B}$ activation was observed at $1 \mathrm{~h}$ culture with maximum activation, which declined at $4 \mathrm{~h}$. An increased amount of activated AP-1 was detected at

a

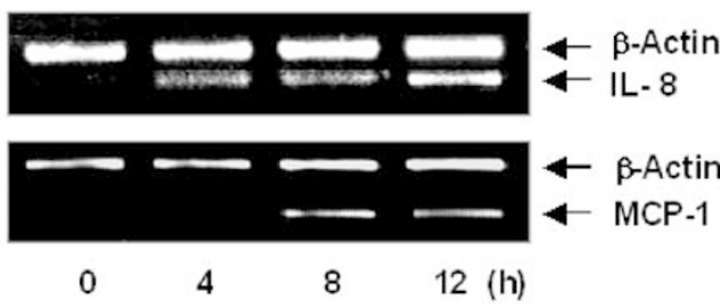

b

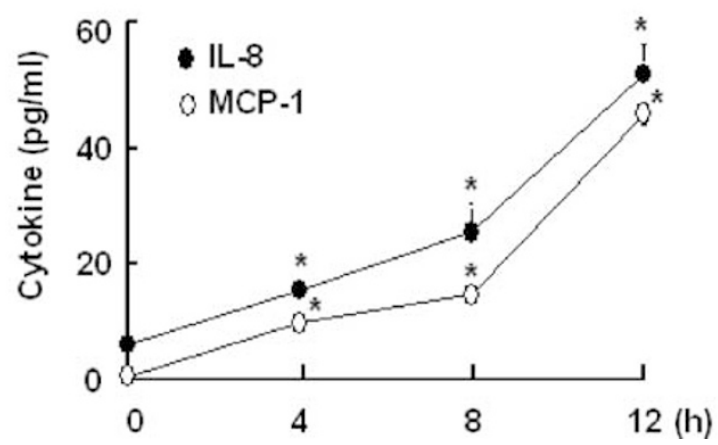

Figure 2 Time-dependent induction of chemokine mRNA (a) and protein (b) by H. pylori in AGS cells. The cells were seeded in 12well culture plates at $10^{5}$ cells per well and cultured to reach $80 \%$ confluency. The bacterial cells were added to the cultured cells at a bacterium/cell ratio of $500: 1$. The cells were homogenized and RNA was extracted for the determination of IL-8 and MCP-1 mRNA expression by RT-PCR. Supernatants were collected for the determination of IL-8 and MCP-1 at the indicated time points. Protein level in the medium was determined by ELISA. The concentration and loading of RNA in each lane was standardized by hybridization with cDNA probe for the constitutively expressed $\beta$-actin (a). Protein level in the medium was expressed as means \pm s.e. of four separate experiments (b). ${ }^{*} P<0.05$ vs value at corresponding $0 \mathrm{~h}$

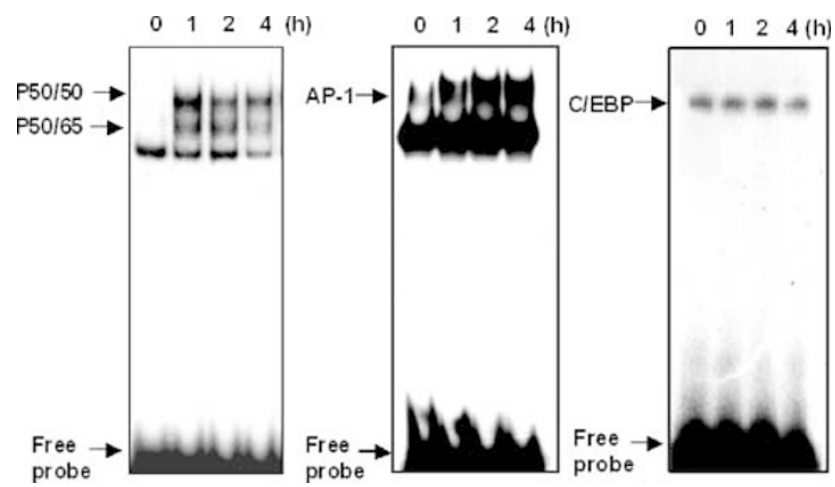

Figure 3 Time course of $H$. pylori-dependent activation of transcription factors in AGS cells. The cells were seeded in 12well culture plates at $10^{5}$ cells per well and cultured to reach $80 \%$ confluency. The bacterial cells were added to the cultured cells at a bacterium/cell ratio of $500: 1$. The cells were harvested and nuclear extracts were subjected to electrophoretic mobility shift assay (EMSA) for the activation of NF- $\kappa$ B, AP-1, and C/EBP at the indicated time points. C/EBP, CCAAT/enhancer binding protein. 
$1 \mathrm{~h}$ and even higher level of activated AP-1 was observed at $4 \mathrm{~h}$. Since C/EBP was not changed by $H$. pylori infection, NF- $\kappa \mathrm{B}$ and $\mathrm{AP}-1$ may contribute to the expression of IL-8 and MCP-1 by $H$. pylori in AGS cells. For the following experiment on transfection with mutant genes and treatment with MAPK inhibitors, $1 \mathrm{~h}$ culture was used for the activation of NF- $\kappa \mathrm{B}$ and AP-1 by $H$. pylori.

\section{Time-dependent Activation of ERK, JNK and p38 by H. pylori}

After addition of bacterial cells to the cultured cells, cell lysates were analyzed for control (Figure 4b) and phospho-specific (Figure 4a) ERK1/2, JNK2/1, and p38 levels by Western blot analysis at the indicated time points. $H$. pylori significantly increased in MAPK phosphorylation. Kinetic analysis indicates that an increase in phospho-specific ERK1/2 was observed at $15 \mathrm{~min}$, with maximum induction achieved $30 \mathrm{~min}$ after $H$. pylori infection and declining thereafter. JNK2/1 phosphorylation was first detected at 15 min with the maximum level

a

Phospho-specific

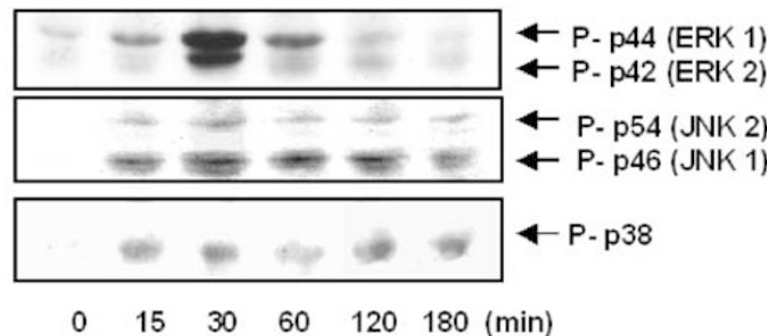

b

Control

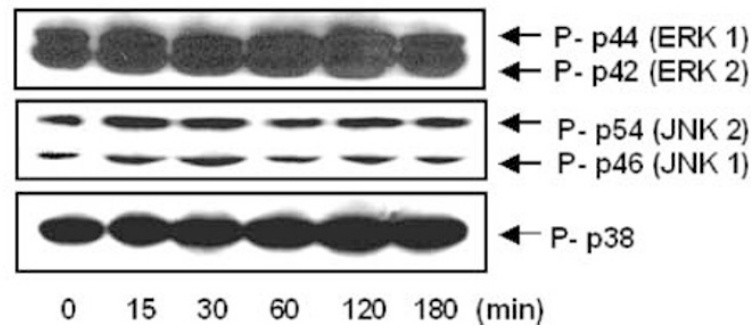

Figure 4 Time-dependent activation of MAPK by $H$. pylori in AGS cells. The cells were seeded in 12-well culture plates at $10^{5}$ cells per well and cultured to reach $80 \%$ confluency. The bacterial cells were added to the cultured cells at a bacterium/ cell ratio of 500:1. Cell lysates were analyzed for control (b) and phospho-specific (a) ERK1/2, JNK2/1, and p38 level by Western blot analysis at the indicated time points. For the detection of control MAPKs, antibodies to pan-ERK1/2, pan-JNK2/1, and panp38 were used. Antibodies to p-ERK1/2, p-JNK2/1, and p-p38 were used for the determination of phospho-specific levels of ERK1/2, JNK2/1, and p38. MAPK, mitogen-activated protein kinase; ERK, extracellular signal-regulated kinase; JNK, c-Jun NH2-terminal protein kinases. at $30 \mathrm{~min}$ and continuously detected until $180 \mathrm{~min}$ after $H$. pylori infection. p38 phosphorylation was also observed at $15 \mathrm{~min}$ after $H$. pylori infection and continued up to $180 \mathrm{~min}$. As shown in Figure 4b, ccntrol MAPKs, determined using antibodies to panERK1/2, pan-JNK2/1, and pan-p38, were not changed by $H$. pylori in AGS cells.

\section{Chemokine mRNA and Protein Expression in AGS Cells Transfected with or without Mutant Genes}

AGS cells transfected with or without mutant genes for ras (ras N-17), c-Jun (TAM-67), and $\mathrm{I} \kappa \mathrm{B} \alpha$ (MAD-3) were cultured in the presence of $H$. pylori for $12 \mathrm{~h}$. The control vector pcDNA3 was transfected to the cells (pcN-3) instead of mutant genes, which was considered as a relative control. RT-PCR showed that $H$. pylori-induced mRNA expression of IL-8 and MCP-1 in control cells without transfection and pcN-3 cells. No cells represent AGS cells without transfection and cultured in the absence of $H$. pylori. H. pylori- induced IL-8 mRNA expression was not observed in the cells transfected with mutant genes (ras N-17, TAM-67, MAD-3). MCP-1 mRNA expression by $H$. pylori was not detected in the cells transfected with ras N-17 and TAM-67, but slightly detected in the cells transfected with MAD-3, even though the level was low (Figure 5a). Similar phenomena were shown in chemokine protein expression in the cells transfected with or without mutant genes (ras N-17, TAM-67, MAD-3), determined by ELISA (Figure 5b). Even though MCP-1 protein expression was relatively slightly affected by $\mathrm{NF}-\kappa \mathrm{B}$, transcription of IL-8 and MCP-1 may be regulated by ras, $\mathrm{AP}-1$, and $\mathrm{NF}-\kappa \mathrm{B}$ in $H$. pyloriinfected AGS cells.

\section{Activation of NF- $\kappa$ B and AP-1 in AGS Cells Transfected with or without Mutant Genes}

AGS cells treated with or without mutant genes for ras (ras N-17), c-Jun (TAM-67), and $\mathrm{I} \kappa \mathrm{B} \alpha$ (MAD-3) were cultured in the presence of $H$. pylori for $1 \mathrm{~h}$ (Figure 6). Nuclear exctracts were subjected to EMSA for the activation of NF- $\kappa$ B and AP-1. The control vector pcDNA3 was transfected to the cells (pcN-3) instead of mutant genes (Figure 6). $H$. pylori-induced activation of NF- $\kappa \mathrm{B}$ and AP-1, shown in control cells without transfection and pcN-3 cells. H. pylori- induced activation of NF- $\kappa \mathrm{B}$ and AP-1 was not observed in the cells transfected with mutant genes (ras N-17, TAM-67, MAD-3). The results show that inhibition of AP-1, by transfection with mutant genes for ras (ras N-17) and c-Jun (TAM-67), may inhibit NF- $\kappa \mathrm{B}$ as transfection with mutant gene for $\mathrm{I} \kappa \mathrm{B} \alpha$ (MAD-3) in $H$. pylori-infected AGS cells. Similarly, inhibition of $\mathrm{NF}-\kappa \mathrm{B}$, by transfection with mutant genes for $\mathrm{I} \kappa \mathrm{B} \alpha$ (MAD-3), may inhibit $\mathrm{AP}-1$ as transfection with mutant genes for ras (ras N-17) and c-Jun 
56

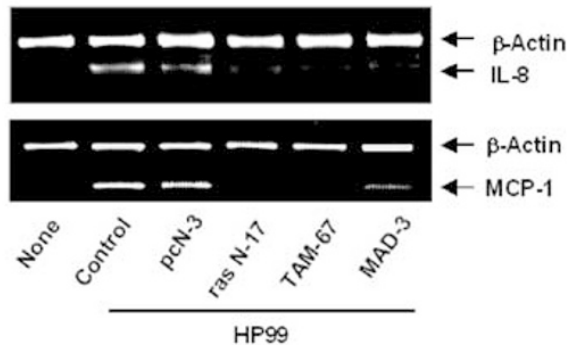

b
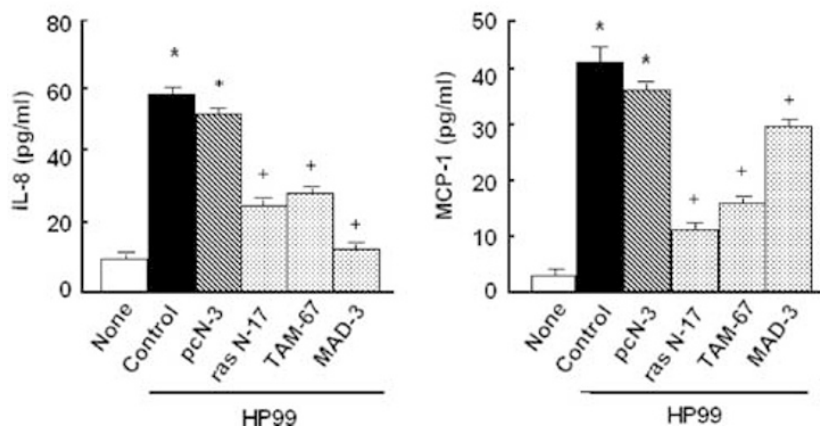

Figure 5 Chemokine mRNA and protein expression in AGS cells transfected with or without mutant genes for ras (ras N-17), c-Jun (TAM-67), and I $\kappa \mathrm{B} \alpha$ (MAD-3). AGS cells transfected with or without mutant genes for ras (ras N-17), c-Jun (TAM-67), and IкB $\alpha$ (MAD-3) were seeded in 12-well culture plates at $10^{5}$ cells per well and cultured to reach $80 \%$ confluency. The bacterial cells were added to the cultured cells at a bacterium/cell ratio of 500:1 for $12 \mathrm{~h}$. The control vector pcDNA3 was transfected to the cells (pcN-3) instead of mutant genes for ras (ras N-17), c-Jun (TAM-67), and I $\mathrm{I} \mathrm{B} \alpha$ (MAD-3). These cells were considered as a relative control. pcN-3, the cells transfected control vector (pcDNA) and cultured in the presence of $H$. pylori; none, AGS cells without transfection and cultured in the absence of $H$. pylori; Control, AGS cells without transfection and cultured in the presence of $H$. pylori. Each bar represents means \pm s.e. of four separate experiments. ${ }^{*} P<0.05$ vs none; ${ }^{+} P<0.05$ vs pcN-3.

(TAM-67), by $H$. pylori in AGS cells. The possible suggestion is that NF- $\kappa \mathrm{B}$ and AP-1 are cross-coupled for the transcription of chemokines, IL-8 and MCP-1, in H. pylori-infected AGS cells.

\section{Chemokine mRNA and Protein Expression in AGS Cells Treated with MAPK Inhibitors}

The MAP kinase inhibitors, U0126 (an ERK inhibitor) and SB203580 (a p38 inhibitor) (at $20 \mu \mathrm{M}$ final concentration), were pretreated to the culture medium $1 \mathrm{~h}$ before the treatment of $H$. pylori. The bacterial cells were added to the cultured cells at a bacterium/cell ratio of 500:1 for $12 \mathrm{~h}$. RT-PCR showed that $H$. pylori-induced mRNA expression of IL-8 and MCP-1 in control cells. H. pylori-induced mRNA expression of IL-8 and MCP-1 was inhibited by treatment of an ERK inhibitor and a p38 inhibitor (Figure 7a). Treatment of an ERK inhibitor and a p38 inhibitor also inhibited chemokine protein expression, determined by ELISA (Figure 7b). The results suggest the involvement of ERK and p38 in the

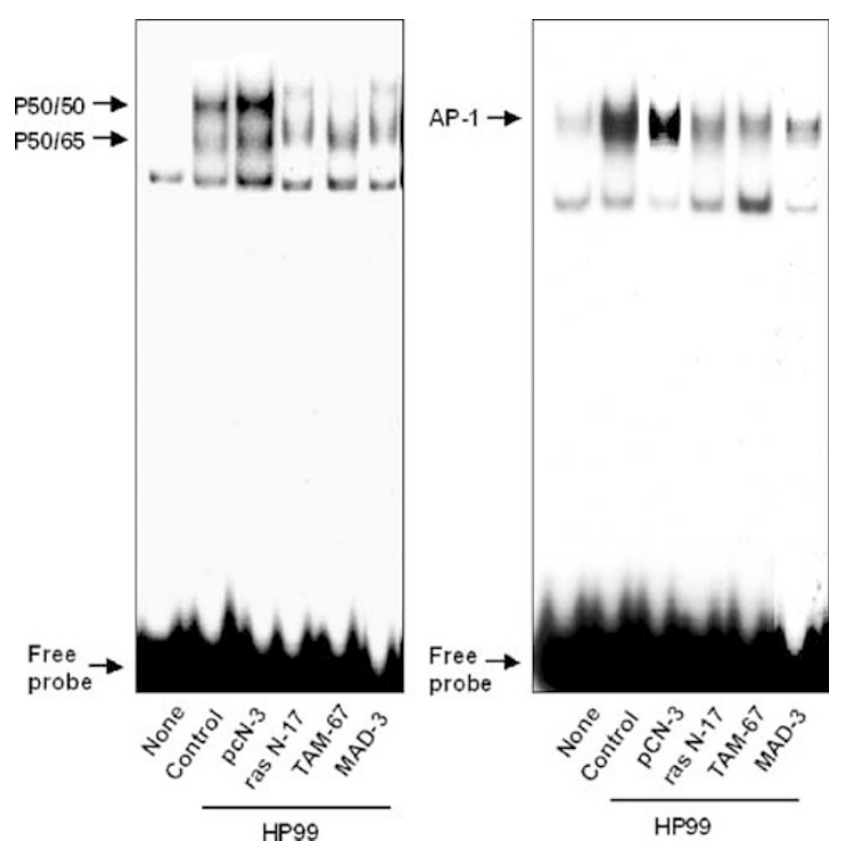

Figure 6 Activation of NF- $\kappa \mathrm{B}$ and AP-1 in AGS cells transfected with or without mutant genes for ras (ras N-17), c-Jun (TAM-67), and IкB $\alpha$ (MAD-3). AGS cells transfected with or without mutant genes for ras (ras N-17), c-Jun (TAM-67), and IкB $\alpha$ (MAD-3) were seeded in 12-well culture plates at $10^{5}$ cells per well and cultured to reach $80 \%$ confluency. The bacterial cells were added to the cultured cells at a bacterium/cell ratio of $500: 1$ for $1 \mathrm{~h}$. The cells were harvested and nuclear extracts were subjected to electrophoretic mobility shift assay (EMSA) for the activation of NF- $\kappa$ B, $\mathrm{AP}-1$, and C/EBP. The control vector pcDNA3 was transfected to the cells (pcN-3) instead of mutant genes for ras (ras N-17), c-Jun (TAM-67), and $\mathrm{I} \kappa \mathrm{B} \alpha$ (MAD-3). These cells were considered as a relative control. pcN-3, the cells transfected control vector (pcDNA) and cultured in the presence of $H$. pylori; none, AGS cells without transfection and cultured in the absence of $H$. pylori; control, AGS cells without transfection and cultured in the presence of $H$. pylori.

expression of IL-8 and MCP-1 in H. pylori-infected AGS cells.

\section{Activation of NF- $\kappa$ B and AP-1 in AGS Cells Treated with MAPK Inhibitors}

AGS cells were pretreated with the MAP kinase inhibitors, U0126 (an ERK inhibitor) and SB203580 (a p38 inhibitor) (at $20 \mu \mathrm{M}$ final concentration), to the culture medium $1 \mathrm{~h}$ before the treatment of $H$. pylori at a bacterium/cell ratio of 500:1. After $1 \mathrm{~h}$, nuclear extracts were extracted and subjected to EMSA for the activation of NF- $\kappa \mathrm{B}$ and AP-1. $H$. pylori-induced activation of NF- $\kappa \mathrm{B}$ and AP-1, which was shown in control cells cultured in the presence of $H$. pylori as compared to no cells cultured in the absence of $H$. pylori. $H$. pyloriinduced activation of NF- $\kappa$ B and AP-1 was inhibited by treatment of an ERK inhibitor and a p38 inhibitor (Figure 8). The results suggest the involvement of MAPK such as ERK and p38 in the activation of NF$\kappa \mathrm{B}$ and AP-1 in $H$. pylori-infected AGS cells. 


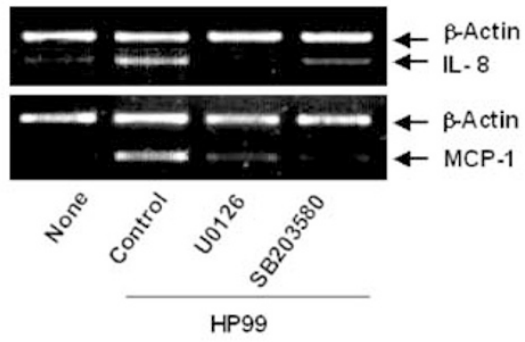

b
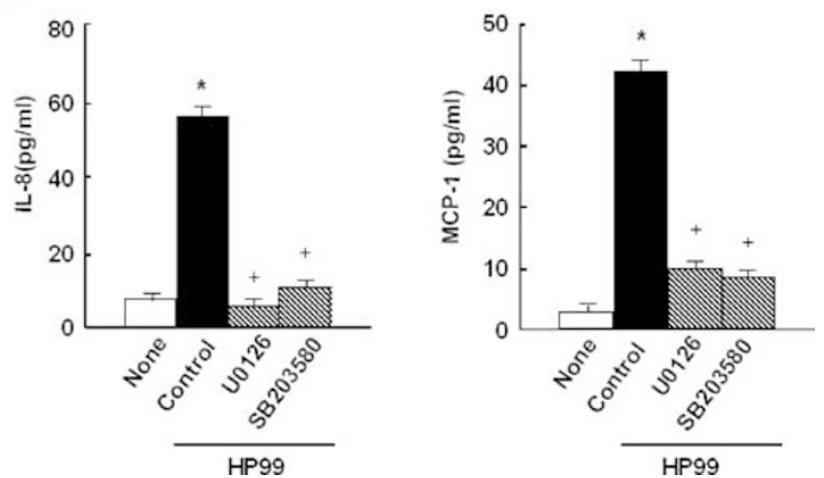

Figure 7 Chemokine mRNA and protein expression in AGS cells treated with MAPK inhibitors. AGS cells were seeded in 12-well culture plates at $10^{5}$ cells per well and cultured to reach $80 \%$ confluency. The MAP kinase inhibitors, U0126 (an ERK inhibitor) and SB203580 (a p38 inhibitor) (at $20 \mu \mathrm{M}$ final concentration), were pretreated to the culture medium $1 \mathrm{~h}$ before the treatment of H. pylori. The bacterial cells were added to the cultured cells at a bacterium/cell ratio of 500:1 for $12 \mathrm{~h}$. None, AGS cells without transfection and cultured in the absence of $H$. pylori; control, AGS cells without transfection and cultured in the presence of $H$. pylori. Each bar represents means \pm s.e. of four separate experiments. ${ }^{*} P<0.05$ vs none; ${ }^{+} P<0.05$ control.

\section{Discussion}

The main finding of this study is that Ras and MAPK cascade may act as the upstream signaling for the activation of $\mathrm{AP}-1$ and $\mathrm{NF}-\kappa \mathrm{B}$, which induce chemokine expression in $H$. pylori-infected AGS cells. We used an $H$. pylori strain HP99 that was isolated from gastric antral mucosa obtained from a Korean patient with duodenal ulcer and identified as $\operatorname{cag} A+$, vacA s1b, m2, ice A1. Expressions of IL-8 and MCP-1 were markedly upregulated at the levels of mRNA and protein, in parallel with the activation of NF- $\kappa \mathrm{B}$ and AP-1 and increase in phospho-specific ERK1/2, JNK2/1 and p38 by HP99 in AGS cells. Expression levels of IL-8 and MCP-1 in HP99infected AGS cells, as well as activation of NF- $\kappa \mathrm{B}$ and AP-1, were inhibited by transfection with mutant genes for Ras (ras N-17), c-Jun (TAM-67), and $\mathrm{I} \kappa \mathrm{B} \alpha(\mathrm{MAD}-3)$ or treatment with MAPK inhibitors (U0126 as an ERK inhibitor or SB203580 as a p38 inhibitor). These results suggest that induction of IL-8 and MCP-1 by $H$. pylori in a Korean isolate may depend on the activation of Ras, MAPK cascade, AP-1, and NF- $\kappa \mathrm{B}$ in gastric epithelial cells.

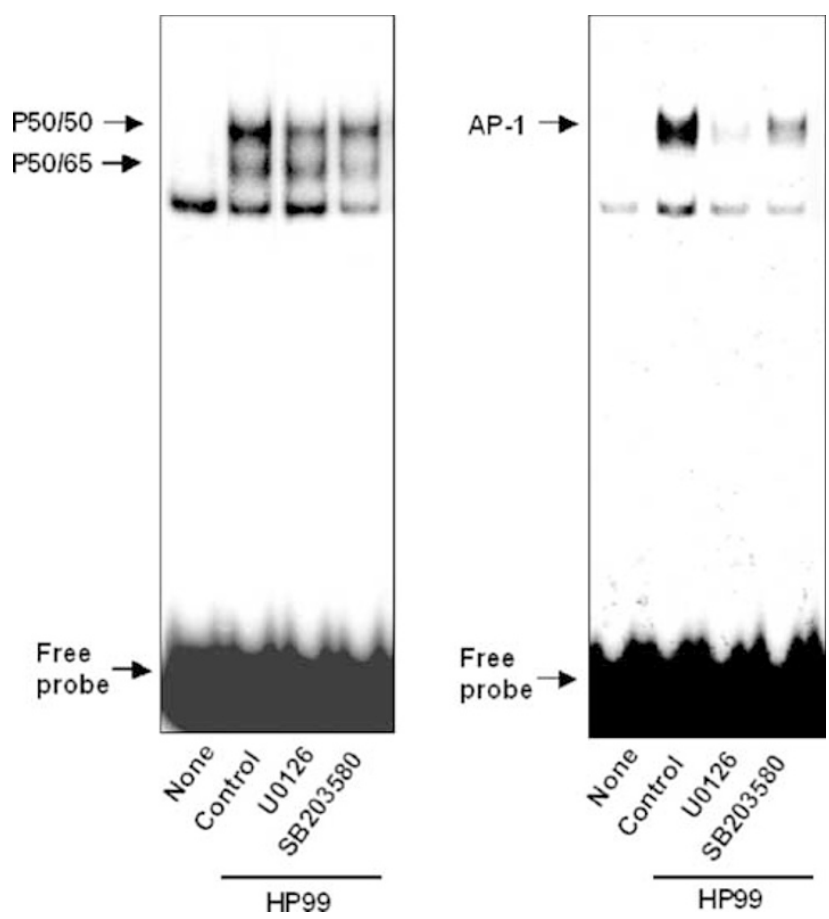

Figure 8 Activation of NF- $\kappa$ B and AP-1 in AGS cells treated with MAPK inhibitors. AGS cells were seeded in 12-well culture plates at $10^{5}$ cells per well and cultured to reach $80 \%$ confluency. The MAP kinase inhibitors, U0126 (an ERK inhibitor) and SB203580 (a p38 inhibitor) (at $20 \mu \mathrm{M}$ final concentration), were pretreated to the culture medium $1 \mathrm{~h}$ before the treatment of $H$. pylori. The bacterial cells were added to the cultured cells at a bacterium/cell ratio of $500: 1$ for $12 \mathrm{~h}$. None, AGS cells without transfection and cultured in the absence of $H$. pylori; control, AGS cells without transfection and cultured in the presence of $H$. pylori.

In addition, inhibition of NF- $\kappa$ B by transfection with mutant genes for $\mathrm{I} \kappa \mathrm{B} \alpha$ (MAD-3) was closely related to inhibition on AP-1 activation by transfection with mutant genes for ras (ras N-17) and c-Jun (TAM-67) in $H$. pylori-infected AGS cells. Both inhibition of $\mathrm{NF}-\kappa \mathrm{B}$ and $\mathrm{AP}-1$ by transfection with mutant genes (ras N-17, TAM-67, MAD-3) similarly inhibited the expression of IL-8 and MCP-1 in H. pylori-infected AGS cells. The results suggest that NF- $\kappa \mathrm{B}$ and AP-1 may be cross-coupled for the transcription of chemokines IL-8 and MCP-1 in H. pylori-infected AGS cells.

The crossactivity between NF- $\kappa \mathrm{B}$ and AP-1 activation was reported in human keratinocytes, ${ }^{53}$ JB6 cells, ${ }^{53}$ and mammary carcinoma cells. ${ }^{57}$ The expression of dominant-negative Jun inhibited elevated AP-1 and NF- $\kappa$ B transactivation and reduced anchorage-independent growth in human keratinocytes. $^{53}$ These results suggest that activation of AP-1 and NF- $\kappa \mathrm{B}$ contributes to neoplastic progression of immortalized human keratinocytes and that specific targeting of the elevated levels seen in benign or malignant tumors might be effective for prevention of treatment of human cancer. ${ }^{53}$ Even though NF- $\kappa$ B and AP-1 represent distinct mammalian transcription factors that target unique DNA enhancer element, the heterodimer of NF- $\kappa$ B (p65/p50) shares 
structural homology with the c-rel proto-oncogene product. Similarly, the AP-1 transcription factor complex is composed of dimmers of c-fos and c-jun proto-oncogenes products. ${ }^{57} \mathrm{c}-\mathrm{Fos}$ and c-Jun are capable of physically interacting with NF- $\kappa \mathrm{B}$ p65 through the Rel homology domain. This complex of NF- $\kappa \mathrm{B}$ p65 and Jun or Fos exhibits enhanced DNA binding and biological function via both the $\kappa \mathrm{B}$ and AP-1 response elements. ${ }^{57}$ Besides, oxidative events regulate $\mathrm{AP}-1$ and $\mathrm{NF}-\kappa \mathrm{B}$ transactivation, these oxidative events can be important molecular targets for cancer prevention. ${ }^{23}$ The induction of IL-8 and MCP-1 occurs at the transcriptional level. The region contains three cis elements important for the induction of IL-8 and MCP-1 gene expression: $\mathrm{NF}-\kappa \mathrm{B}$, AP-1, and C/EBP binding sites. IL-8 and MCP-1 gene transcriptions require the activation of the combination of transcription factor NF- $\kappa \mathrm{B}$ and AP-1 or that of NF- $\kappa$ B and C/EBP, depending on the types of cell or stimuli). ${ }^{58,59}$ The present study showed that C/EBP was not involved in $H$. pyloriinduced IL-8 and MCP-1 expression in AGS cells, which was determined by EMSA.

Keates et $a l^{48}$ reported that direct contact of $H$. pylori with gastric epithelial cells activates NF$\kappa \mathrm{B}$ in vitro. Both the phosphorylation and proteolytic degradation of $\mathrm{I} \kappa \mathrm{B} \alpha$ allows the release and nuclear transmigration of NF- $\kappa \mathrm{B}$, which may be induced by oxygen radicals. ${ }^{14,15}$ Some evidence shows that $H$. pylori-induced MCP-1 expression is mediated by NF- $\kappa \mathrm{B}$ in gastric epithelial cells. ${ }^{20,21}$ Oxygen radicals were produced by the association of $H$. pylori with gastric epithelial cells. We previously demonstrated that lipid peroxidation, an index of oxidative membrane damage, increased by $H$. pylori in gastric epithelial AGS and Kato III cells, which was in parallel with a time-course stimulation of IL-8 production. ${ }^{4,5}$ More recently, Shimoyama et al ${ }^{60}$ reported that oxygen radicals are important mediators for chemokine expression in human neutrophils stimulated by $H$. pylori. Since oxidative stress is an important regulator of chemokine gene expression and an inducer of the NF- $\kappa \mathrm{B}$ and AP-1, ${ }^{14,15,23}$ antioxidants might be beneficial for the treatment of $H$. pylori-induced gastric mucosal injury and inflammation caused by oxidant-mediated chemokine production.

H. pylori-induced expressions of IL-8 and MCP-1 were shown in gastric epithelial cells ${ }^{11,61}$ and gastric mucosa tissues of the patients. ${ }^{62}$ AP-1 has been known as an oxidant-sensitive or antioxidantresponsive factor depending on cell types. ${ }^{63}$ In $H$. pylori-induced IL-8 gene transcription in MKN 45 cells $^{17}$ and KATO III cells, ${ }^{18}$ the activation of both $\mathrm{NF}-\kappa \mathrm{B}$ and, to a lesser extent, AP-1 was induced for IL-8 gene transcription. Our previous study ${ }^{19}$ demonstrated the importance of AP-1 as much as NF$\kappa \mathrm{B}$ for IL-8 expression by $H$. pylori in AGS cells. We characterized the AP-1 component activated by $H$. pylori as a heterodimer of c-Fos/c-Jun, which might be induced by oxygen radicals. ${ }^{19}$ This hypothesis was proven by the inhibitory effect of $N$-acetylcysteine on the activation of these transcription factors, $\mathrm{NF}-\kappa \mathrm{B}$ and AP-1, and IL-8 expression in AGS cells. $N$-acetylcysteine increases the intracellular stores of glutathione in the cells, thereby enhancing endogenous antioxidative defense mechanism. ${ }^{64}$ IL-8 gene transcription requires the activation of the combination of transcription factor NF- $\kappa \mathrm{B}$ and AP-1 or that of NF- $\kappa \mathrm{B}$ and C/EBP, depending on the types of cells or stimuli. ${ }^{58,59}$ In this study, we show that C/ EBP is not involved in $H$. pylori-induced IL-8 and MCP-1 expression in AGS cells. This is supported by the observation that there is no decrease in the induction of luciferase activity from AGS cells transfected with luciferase expression vector linked to IL-8 gene, but containing mutant C/EBP-binding site as described in our previous study. ${ }^{19}$

AP-1 activity is regulated by all three MAPK pathways. ${ }^{24}$ Regulation occurs both at the transcriptional level and at the post-transcriptional level. The expression of c-fos, which is nearly absent in quiescent cells, is controlled at the level of transcription. All three MAPKs, ERK1/2, SAPK/JNK, and p38, can phosphorylate the transcription factor Elk-1, a member of the complex family. ${ }^{65,66}$ Elk-1 binds the serum response element motif in the c-fos promoter, thereby inducing c-fos transcription. ${ }^{25}$ In contrast, c-jun is regulated both transcriptionally and post-transcriptionally. A few c-Jun homodimers pre-exist in resting cells. In addition, c-jun transcription is upregulated by activated MAPK. ${ }^{26}$ Subsequently, c-Jun can increase its own transcription by binding to the TRE motif in its promoter. ${ }^{67}$ Novel cFos synthesis leads to the formation of Jun/ Fos heterodimers, which have a 10 -fold higher DNA binding affinity than Jun/Jun homodimers, resulting in increased AP-1 activity. ${ }^{68}$ Post-transcriptionally, c-Jun activity is potentiated through phosphorylation of the transcriptional activator domain by SAPK/JNK. ${ }^{27}$ A variety of extracellular stimuli induce ras activation, resulting in activation of the ras/raf/ERK kinase (MEK)/MAPK cascade. ${ }^{30}$ The Ras-Raf pathway increases the transcriptional activity of transcription factors, such as c-Jun, and important components of AP- $1 .^{31}$ Ras dominantnegative gene expression almost blocked p38 phosphorylation in smooth muscle cells. ${ }^{32} H$. pylori activated AP-1 through ERK signaling ${ }^{22,28}$ and JNK signaling $^{29}$ in gastric epithelial cells. H. pyloriinduced IL-8 expression was reported to be mediated by AP-1 through ERK in gastric cancer cells. ${ }^{28,69} H$. pylori cagA induced ras activation and Elk-phosphorylation in gasrtic epithelial cells. ${ }^{70}$ The present activated AP-1 by $H$. pylori was inhibited by treatment of the MAP kinase inhibitors, U0126 (an ERK inhibitor) and SB203580 (a p38 inhibitor), and transfection with ras dominant-negative mutant gene (ras N-17) and c-Jun dominant-negative mutant gene (TAM-67). The results clearly show that $H$. pylori-induced activation of AP-1 involves Ras, MAPK, and c-Jun in AGS cells. 
$\mathrm{NF}-\kappa \mathrm{B}$ activation is tightly regulated by its endogenous inhibitor, I $\kappa \mathrm{B}$, which complexes NF$\kappa \mathrm{B}$ in the cytoplasm. To date, the most extensively studied $\mathrm{I} \kappa \mathrm{B}$ protein is $\mathrm{I} \kappa \mathrm{B} \alpha(36 \mathrm{kDa})$ encoded by the human MAD-3 gene or its homologues in different species. ${ }^{71}$ The mechanisms that lead to the degradation of $\mathrm{I} \kappa \mathrm{B} \alpha$ proteins are poorly understood, but involve changes in the phosphorylation state of $\mathrm{I} \kappa \mathrm{B} \alpha .{ }^{15}$ Two serines in the N-terminal domain of $\mathrm{I} \kappa \mathrm{B} \alpha$, serine residues 32 and 36 , were shown to be critical for $\mathrm{I} \kappa \mathrm{B} \alpha$ stability. ${ }^{72}$ Substitution of these two serine residues by alanine residues rendered $\mathrm{I} \kappa \mathrm{B} \alpha$ undegradable by cellular activators. ${ }^{72}$ Among the many proteins exhibiting $\mathrm{I} \kappa \mathrm{B}$ function, $\mathrm{I} \kappa \mathrm{B} \alpha$ is the only inhibitor that, in response to cell stimulation, dissociates from the NF- $\kappa \mathrm{B}$ complex, with kinetics matching NF- $\kappa \mathrm{B}$ translocation to the nucleus. ${ }^{73}$ It was therefore suggested that the activation of NF- $\kappa \mathrm{B}$ is mainly regulated by $\mathrm{NF}-\kappa \mathrm{B} / \mathrm{I} \kappa \mathrm{B} \alpha$ dissociation. Such a mutant $\mathrm{I} \kappa \mathrm{B} \alpha$ has been shown to act as an NF- $\kappa \mathrm{B}$ super-repressor. ${ }^{74} \mathrm{~A}$ dominant-negative mutant of c-jun, called TAM-67, is a potent inhibitor of AP-1-mediated transactivation. ${ }^{50}$ A dominant-negative mutant lacking the transactivation domain of cJun can dimerize with c-jun or c-fos family members, and can bind DNA. Thus, such a mutant could inhibit the function of wild-type c-Jun and c-Fos through either a blocking or quenching mechanism. ${ }^{51}$ Transfection of a dominant-negative mutant of ras, called ras $\mathrm{N}-17$, into the cells interferes with ras function by the expression of a dominant inhibitory mutation in c-Ha-ras. This mutation changes serine17 to arginine-17 in the gene product and thus inhibits ras activity. ${ }^{52}$

For the virulence factors known in $H$. pylori strains, vacA, encoding the vacuolating toxin, is present in all strains ${ }^{45,54}$ and comprises two regions of allelic variation. ${ }^{4}{ }^{4}$ The s-region, located at the $5^{\prime}$ end of the gene, and the m-region, located in the middle of vacA, has three allelic forms. ${ }^{46,47}$ The production of the cytotoxin is related to the mosaic combination of s- and m-region alleles in vacA. The vacA $\mathrm{s} 1 / \mathrm{m} 1$ strains have higher cytotoxic activity than $\mathrm{s} 1 / \mathrm{m} 2$ strains ${ }^{44}$ vacA m1-type strains are associated with greater gastric epithelial damage than m2 strains ${ }^{45}$ Even though we did not compare the cytotoxicity between present HP99 (vacA s1b/ $\mathrm{m} 2$ strain) and other vacA s1/m1 strains, HP99 significantly activated NF- $\kappa \mathrm{B}$ and $\mathrm{AP}-1$ and thus induced chemokine expression in AGS cells. The cytotoxin-associated gene $(\operatorname{cag} A)$ is expressed by the majority of the cytotoxin ( $\mathrm{vacA}$ )-positive isolates. ${ }^{55}$ This gene is a marker for the presence of a multigenic $40 \mathrm{~kb}$ region of the genome, called the cag pathogenicity island. ${ }^{55}$ Infection by $\operatorname{cag} A+$ strains is more likely to result in peptic ulceration, ${ }^{55}$ atrophic gastritis, ${ }^{35}$ and gastric carcinoma. ${ }^{36}$ Meerter-Vehn et $a l^{22}$ determined that $H$. pylori induces AP-1 activity in gastric epithelial cells. $H$. pylori strongly induced AP-1 DNA binding and selectively activated the ERK/MAPK cascade. The stimulation of ERK led to phosphorylation of the transcription factor Elk-1 and markedly increased c-fos transcription. At the protein level, the expression of c-Fos and phosphorylation of c-Jun was strongly induced. $H$. pylori strains that did not express $\operatorname{cag} A$ did not induce AP-1, MAPK activity, c-fos, or c-jun expression. Another putative virulence gene has recently been described and is designated ice $A .{ }^{56}$ The ice $A$ locus comprises two main variants, ice $A 1$ and ice $A 2$. The function of these variants is not yet clear. The expression of iceA1 is upregulated by contact of the bacteria with human gastric epithelial cells and in some populations is associated with peptic ulcer disease. ${ }^{47,56}$ After examining 94 gastric biopsy specimens from the patients in the Netherlands, van Doorn et $a l^{47}$ reported that the ice $A$ allelic type was independent of the $\operatorname{cag} A$ and $\operatorname{vac} A$ status, and there was a significant association between the presence of the iceA1 allele and peptic ulcer disease. Figueiredo et $a l^{75}$ demonstrated that vacA s1 and $\operatorname{cag} A+H$. pylori strains are associated with duodenal ulcer, gastric ulcer, or gastric carcinoma in Portugal. VacA $\mathrm{m} 1$ is associated with gastric ulcer or carcinoma, but not with duodenal ulcer. Since HP99 is $\operatorname{cag} A+, \operatorname{vac} A \mathrm{~s} 1 \mathrm{~b}, \mathrm{~m} 2$, ice $A 1 H$. pylori strain and induced significant activation of NF- $\kappa \mathrm{B}$ and AP-1 and thus, induction of chemokines, IL-8 and MCP-1, in AGS cells, this strain may be cytotoxic to gastric epithelial cells.

The present results demonstrate that the expressions of IL-8 and MCP-1 by $H$. pylori in a Korean isolate (HP99; $\operatorname{cag} A+$, vacA s1b, $\mathrm{m} 2$, ice $A 1 H$. pylori strain) are regulated by the transcription factors NF$\kappa \mathrm{B}$ and AP-1, mediated by Ras and MAPK, in gastric epithelial cells. Further studies on the signaling pathways and mediators induced by $H$. pylori infection, depending on the virulence factors and $H$. pylori strains, are necessary to provide better understanding and rational approaches for the control of this inflammation process.

\section{Acknowledgement}

Supported by a Grant from the Korea Science and Engineering Foundation made in the program year of 2002 (to HK).

\section{References}

1 Marshall DG, Coleman DC, Sullivan DJ, et al. Genomic DNA fingerprinting of clinical isolates of Helicobacter pylori using short oligonucleotide probes containing repetitive sequences. J Appl Bacteriol 1996;5:191-202.

2 Parsonnet J, Friedman GD, Vandersteen DP, et al. Helicobacter pylori infection and the risk of gastric carcinoma. N Engl J Med 1991;325:1127-1131.

3 Grisham DY. Pathogenic mechanisms loading to Helicobacter pylori-induced inflammation. Eur J Gastroenterol Hepatol 1992;4:S9-S16. 
$4 \mathrm{Kim} \mathrm{H}$, Seo JY, Kim KH. Effects of mannitol and dimethylthiourea on Helicobacter pylori-induced IL-8 production in gastric epithelial cells. Pharmacology 1999;59:201-211.

5 Kim H, Seo JY, Kim KH. Inhibition of lipid peroxidation NF- $\kappa$ B activation and IL-8 production by rebamipide in Helicobacter pylori-stimulated gastric epithelial cells. Dig Dis Sci 2000;45:621-628.

6 Baggiolini M, Loetscher P, Moser B. Interleukin-8 and the chemokine family. Int J Immunopharmacol 1995;17:103-108.

7 Ben-Baruch A, Michiel DF, Oppenheim JJ. Signals and receptors involved in recruitment of inflammatory cells. J Biol Chem 1995;270:11703-11706.

8 Fan XG, Chua A, Fan XJ, et al. Increased gastric production of inlerleukin-8 of tumor necrosis factor in patients with Helicobacter pylori infection. J Clin Pathol 1995;48:133-136.

9 Huang J, O'Toole PW, Doig P, et al. Stimulation of interleukin-8 production in epithelial cell lines by Helicobacter pylori. Infect Immun 1995;63:1732-1738.

10 Ando T, Kusugami K, Ohsuga M, et al. Interleukin-8 activity correlates with histological severity in Helicobacter pylori-associated antral gastritis. Am J Gastroenterol 1996;91:1150-1156.

11 Watanabe N, Shimada T, Ohtsuka Y, et al. Proinflammatory cytokines and Helicobacter pylori stimulate CC-chemokine expression in gastric epithelial cells. J Physiol Pharmacol 1997;48:405-413.

12 Roebuck KA. Oxidant stress regulation of IL-8 and ICAM-1 gene expression: differential activation and binding of the transcription factors AP-1 and NF- $\kappa \mathrm{B}$. Int J Mol Med 1999;4:223-230.

13 Muller JM, Rupec RA, Baeuerle PA. Study of gene regulation by $\mathrm{NF}-\kappa \mathrm{B}$ and $\mathrm{AP}-1$ in response to reactive oxygen intermediates. Methods: A Companion to Methods Enzymol 1997;11:301-312.

14 Siebenlist U, Franzoso G, Brown K. Structure, regulation and function of NF- $\kappa$ B. Annu Rev Cell Biol 1994;10:405-455.

15 Thanos D, Maniatis T. NF-kappa B: a lesion in family values. Cell 1995;80:529-532.

$16 \mathrm{Lim}$ JW, Kim H, Kim KH. NF- $\kappa$ B, inducible nitric oxide synthase and apoptosis by Helicobacter pylori infection. Free Rad Biol Med 2001;31:355-366.

17 Aihara M, Tsuchimoto D, Takizawa H, et al. Mechanisms involved in Helicobacter pylori-induced interleukin-8 production by a gastric cancer cell line, MKN45. Infec Immun 1997;65:3218-3224.

18 Masamune A, Shimosegawa T, Masamune O, et al. Helicobacter pylori-dependent ceramide production may mediate increased interleukin 8 expression in human gastric cancer cell lines. Gastroenterology 1999;116:1330-1341.

19 Chu SH, Kim H, Seo JY, et al. Role of NF- $\kappa$ B and AP-1 on Helicobacter pylori- induced IL-8 expression in AGS cells. Dig Dis Sci 2003;48:257-265.

20 Cottet S, Corthesy-Theulaz I, Spertini F, et al. Microaerophilic conditions permit to mimic in vitro events occurring during in vivo Helicobacter pylori infection and identify Rho/Ras-associated proteins in cellular signaling. J Biol Chem 2002;277:33978-33986.

21 Mori K, Ueda A, Geleziunas R, et al. Induction of monocyte chemoattractant protein-1 by Helicobacter pylori involves NF- $\kappa \mathrm{B}$. Infec Immune 2001;69: 1280-1286.
22 Meyer-ter-Vehn T, Covacci A, Kist M, et al. Helicobacter pylori activates mitogen-activated protein kinase cascade and induces expression of the proto-oncogene c-fos and c-jun. J Biol Chem 2000;275:16064-16072.

23 Hsu TC, Young MR, Cmarik J, et al. Activator protein 1 and nuclear factor $\kappa \mathrm{B}$-dependent transcription events in carcinogenesis. Free Rad Biol Med 2000;28: 1338-1348.

24 Whitmarsh AJ, Davis RJ. Transcription factor AP-1 regulation by mitogen-activated protein kinase signal transduction pathways. J Mol Med 1996;74:589-607.

25 Hipskind RA, Rao VN, Mueller CG, et al. Nordheim A. Ets-related Elk-1 is homologous to the c-fos regulatory factor p62TCF. Nature 1991;354:531-534.

26 Lamph WW, Wamsley $\mathrm{P}$, Sassone-Corsi $\mathrm{P}$, et al. Induction of proto-oncogene JUN/AP-1 by serum and TPA. Nature 1988;334:629-631.

27 Derijard B, Hibi M, Wu IH, et al. JNK1: a protein kinase stimulated by UV light and Ha-Ras that binds and phosphorylates the c-Jun activation domain. Cell 1994;76:1025-1037.

28 Matsuno Y, Yoshida H, Maeda S, et al. Helicobacter pylori induced transactivation of SRE and AP-1 through the ERK signaling pathway in gastric cancer cells. Gut 2002;49:18-22.

29 Naumann M, Wessler S, Bartsch C, et al. Activation of activator protein-1 and stress response kinase in epithelial cells colonized by Helicobacter pylori encoding cag pathogenicity island. J Biol Chem 1999;274:31655-31662.

30 Garrington TP, Johnson GL. Organization and regulation of mitogen-activated protein kinase signaling pathways. Curr Opin Cell Biol 1999;11:211-218.

31 Binetruy B, Smeal T, Karin M. Ha-Ras augments c-Jun activity and stimulates phosphorylation of its activation domain. Nature (London) 1991;351:122-127.

$32 \mathrm{Li} \mathrm{C}, \mathrm{Hu} \mathrm{Y}$, Sturm G, et al. Ras/Rac-dependent activation of p38 mitogen-activated protein kinases in smooth muscle cells stimulated by cyclic strain stress. Arterioscler Thromb Vasc Bio 2000;20:e1-e9.

33 Akopyants NS, Clifton SW, Kersulyte D, et al. Analyses of the cag pathogenicity island of Helicobacter pylori. Mol Microbiol 1998;28:37-54.

34 Keates S, Keates AC, Warny M, et al. Differential activation of mitogen-activated protein kinases in AGS gastric epithelial cells by $\mathrm{cag}^{+}$and $\mathrm{cag}^{-}$Helicobacter pylori. J Immunol 1999;163:5552-5559.

35 Kuipers EJ, Perez-Perez GI, Meuwissen SG, et al. Helicobacter pylori and atrophic gastritis: importance of the cagA status. J Natl Cancer Inst 1995;87: 1777-1780.

36 Blaser MJ, Perez-Perez GI, Kleanthous H, et al. Infection with Helicobacter pylori strains possessing cagA is associated with an increased risk of developing adenocarcinoma of the stomach. Cancer Res 1995;55:2111-2115.

37 Achtman M, Azuma T, Berg DE, et al. Recombination and clonal groupings within Helicobacter pylori from different geographic regions. Mol Microbiol 1999;32:459-470.

38 Labigne A, de Reuse H. Determinants of Helicobacter pylori pathogenicity. Infect Agents Dis 1996;5: 191-202.

39 Mobley HL. Defining Helicobacter pylori as a pathogen: strain heterogenicity and virulence. Am J Med 1997;100:2S-11S. 
40 Miehlke S, Kibler K, Kim JG, et al. Allelic variation in the cagA gene of Helicobacter pylori obtained from Korea compared to the United States. Am J Gastroenterol 1996;91:1322-1325.

41 Yamaoka Y, Kodama T, Gutierrez O, et al. Relationship between Helicobacter pylori iceA, cagA, and vacA status and clinical outcome: studies in four different countries. J Clin Microbiol 1999;37:2274-2279.

$42 \mathrm{Kim}$ JS, Jung HS, Kim JM, et al. Interleukin-8 expression by human neutrophils activated by Helicobacter pylori soluble proteins. Scan J Gastroenterol 1998;33:1249-1255.

43 Kim JS, Jung HS, Kim JM, et al. Helicobacter pylori water-soluble surface proteins activate human neurtophils and upregulate the expression of CXC chemokines. Dig Dis Sci 2000;45:83-92.

44 Atherton JC, Cao P, Peek RMJ, et al. Mosaicism in vacuolating cytotoxin alleles of Helicobacter pylori. Association of specific vacA types with cytotoxin production and prptic ulceration. J Biol Chem 1995;270:17771-17777.

45 Atherton JC, Peek RMJ, Tham KT, et al. Clinical and pathological importance of heterogenicity on vacA, the vacuolating cytotoxin gene of Helicobacter pylori. Gastroenterology 1997;112:92-99.

46 Van Doorn LJ, Figueiredo C, Sanna R, et al. Clinical relevance of the cagA* vacA* and iceA status of Helicobater pylori. Gastroenterology 1998;115:58-66.

47 Van Doorn LJ, Figueiredo C, Sanna R, et al. Expanding allelic diversity of Helicobacter pylori vacA. J Clin Microbiol 1998;36:2597-2603.

48 Keates S, Hitti YS, Upton M, et al. Helicobacter pylori infection activates $\mathrm{NF}-\kappa \mathrm{B}$ in gastric epithelial cells. Gastroenterology 1997;113:1099-1109.

49 Traenckner EB, Pahl HL, Henkel T, et al. Phosphorylation of human Icon serines 32 and 36 controls $\mathrm{I} \kappa \mathrm{B} \alpha$ proteolysis and $\mathrm{NF}-\kappa \mathrm{B}$ activation in response to diverse stimuli. EMBO J 1995;14:2876-2883.

50 Brown PH, Chen TK, Birrer MJ. Mechanism of action of a dominant-negative mutant of c-Jun. Oncogene 1994;9:791-799.

51 Brown PH, Alani R, Preis LH, et al. Suppression of oncogene-induced transformation by a deletion mutant of c-jun. Oncogene 1993;8:877-886.

52 Cai H, Szeberenyi J, Cooper GM. Effect of a dominant inhibitory Ha-ras mutation on mitogenic signal transduction in NIH 3T3 cells. Mol Cell Biol 1990;10: 5314-5323.

$53 \mathrm{Li} \mathrm{J-J,} \mathrm{Rhim} \mathrm{JS,} \mathrm{Schlegel} \mathrm{R,} \mathrm{et} \mathrm{al.} \mathrm{Expression} \mathrm{of}$ dominant negative Jun inhibits elevated AP-1 and $\mathrm{NF}-\kappa \mathrm{B}$ transactivation and suppress anchorage independent growth of HPV immortalized human keratinocytes. Oncogenes 1998;16:2711-2721.

54 Cover TL. The vacuolating ctotoxin of Helicobacter pylori. Mol Microbiol 1996;20:241-246.

55 Covacci A, Censini S, Bugnoli M, et al. Molecular characterization of the $128-\mathrm{kDa}$ immunodominant antigen of Helicobacter pylori-associated with cytotoxicity and duodenal ulcer. Proc Natl Acad Sci USA 1993;90:5791-5795.

56 Peek RMJ, Thompson SA, Donahue JP, et al. Adherence to gastric epithelial cells induces expression of a Helicobacter pylori gene, iceA, that is associated with clinical outcome. Proc Assoc Am Phys 1998;110: 532-544.

57 Stein B, Baldwin Jr AS, Ballard DW, et al. Crosscoupling of the NF- $\kappa \mathrm{B}$ p65 and Fos/Jun transcription factors produces potentiated biological function. EMBO J 1993;12:3879-3891.

58 Matsusaka T, Fujikawa K, Nishio Y, et al. Tanscripton factors NF-IL-6 and NF- $\kappa$ B synergistically activate transcription of the inflammatory cytokines* interleukin 6 and interleukin 8. Proc Natl Acad Sci USA 1993;90:10193-10197.

59 Mukaida N, Mahe Y, Matsushima K. Cooperative interaction of nuclear factor $\kappa \mathrm{B}$ - and cis-regulatory enhancer binding protein-like factor binding elements in activating the interleukin-8 gene by proinflammatory cytokines. J Biol Chem 1990;265:21128-21133.

60 Shimoyama T, Fukuda S, Liu Q, et al. Production of chemokines and reactive oxygen species by human neutrophils stimulated by Helicobacter pylori. Helicobacter 2002;7:170-174.

61 Jung HC, Kim JM, Song IS, et al. Helicobacter pylori induces an array of pro-inflammatory cytokines in human gastric epithelial cells: quantification of mRNA for interleukin $-8^{*}-1$ alpha/beta, granulocyte-macrophage colony-stimulating factor, monocyte chemoattractant protein-1 and tumor necrosis factor-alpha. J Gastroenterol Hepatol 1997;12:473-480.

62 Shimoyama T, Everett SM, Dixon MF, et al. Chemokine mRNA expression in gastric mucosa is associated with Helicobacter pylori cagA positivity and severity of gastritis. J Clin Pathol 1998;51:765-770.

63 Schenk H, Klein M, Erdbrugger W, et al. Distinct effects of thioredoxin and antioxidants on the activation of transcription factors NF- $\kappa \mathrm{B}$ and AP-1. Proc Natl Acad Sci USA 1994;91:1672-1676.

64 Seo JY, Kim H, Kim KH. Transcriptional regulation by thiol compounds in Helicobacter pylori-induced interleukin-8 production in human gastric epithelial cells. Ann NY Acad Sci 2002;973:541-545.

65 Zinck R, Cahill MA, Kracht M, et al. Protein synthesis inhibitors reveal differential regulation of mitogenactivated protin kinase and stress-activated protein kinase pathways that converge on Elk-1. Mol Cell Biol 1995;15:4930-4938.

66 Rinegaud J, Whitmarsh AJ, Barrett T, et al. MKK3- and MKK6-regulated gene expression is mediated by the p38 mitogen-activated protein kinase signal transduction pathway. Mol Cell Biol 1996;16:1247-1255.

67 Talley NJ, Zinsmeister AR, Weaver A, et al. Gastric adenocarcinoma and Helicobacter pylori infection. J Natl Cancer Inst 1991;83:1734-1739.

68 Han TH, Prywes R. Regulatory role of MEF2D in serum induction of the c-jun promoter. Mol Cell Biol 1995;15:2907-2915.

69 Keates S, Sougioultzis S, Keates AC, et al. Cag+ Helicobacter pylori induce transactivation of the epidermal growth factor receptor in AGS gastric epithelial cells. J Biol Chem 2001;276:48127-48134.

70 Hirata Y, Maeda S, Mitsuno Y, et al. Helicobacter pylori CagA protein activates serum response element-driven transcription independently of tyrosine phosphorylation. Gastroenterology 2002;123:1962-1971.

71 Haskill S, Beg AA, Tompkins SM, et al. Characterization of an immediate-early gene induced in adherent monocytes that encodes I kappa B-like activity. Cell 1991;65:1281-1289.

72 Brown K, Gersberger S, Carlson L, et al. Control of $\mathrm{I} \kappa \mathrm{B} \alpha$ proteolysis by site-specific, signal-induced phosphorylation. Science 1995;267:1485-1488.

73 Sun SC, Ganchi PA, Beraud C, et al. Autoregulation of the NF- $\kappa$ B transactivator Rel A (p65) by multiple 
cytoplasmic inhibitors containing ankyrin motifs. Proc Natl Acad Sci USA 1994;91:1346-1350.

74 Wang CY, Mayo MW, Baldwin Jr AS. TNF- $\alpha$ and cancer therapy-induced apoptosis: potentiation by inhibition of NF- $\kappa$ B. Science 1996;274:784-787.
75 Figueiredo C, Van Doorn L-J, Nogueira C, et al. Helicobacter pylori genotypes are associated with clinical outcome in Portuguese patients and show a high prevalence of infections with multiple strains. Scand J Gastroenterol 2001;36:128-135. 